\author{
Sabina Sanetra-Pólgrabi \\ Uniwersytet Pedagogiczny \\ im. Komisji Edukacji Narodowej \\ w Krakowie
}

\title{
Instytucje ekonomii społecznej w warunkach kryzysu gospodarczego (na przykładzie podmiotów w województwie śląskim)
}

\author{
Social economy institutions in the conditions of an economic crisis \\ (on the example of the Silesia region)
}

\begin{abstract}
Streszczenie
W społecznościach lokalnych coraz częściej poszukuje się aktywnych i skutecznych sposobów wspierania zatrudniania osób wykluczonych. Obok instrumentów prawnych i finansowych ważne są też instytucje ekonomii społecznej. Okazuje się, że miasta, które mają tego typu instytucje, osiągają dużo lepsze wyniki gospodarcze, są atrakcyjniejsze dla inwestorów i cechują się mniejszym bezrobociem, niż miasta, które ich nie mają. Niniejszy tekst przedstawia znaczenie instytucji ekonomii społecznej w województwie śląskim. Analiza wykazała, że w regionie funkcjonuje 41 takich podmiotów, zwłaszcza spółdzielni socjalnych, towarzystw ubezpieczeń wzajemnych, fundacji rozwoju przedsiębiorczości, przedsiębiorstw społecznych, organizacji pozarządowych czy centrów aktywności społecznej. W artykule skupiono się na działalności wybranych instytucji, ukazano ich rolę w regionie, specyfikę funkcjonowania, główne osiągnięcia. Punktem wyjścia stało się zdefiniowanie podstawowych pojęć związanych w sposób bezpośredni z ekonomią społeczną, a także odniesienie się do roli tego sektora i znaczenia klimatu organizacyjnego oraz instytucjonalnego, korzystnego dla prawidłowego funkcjonowania tych podmiotów.
\end{abstract}

\begin{abstract}
Local communities are increasingly searching for active and effective ways to promote the employment of the excluded. Social economy institutions play an important part in that process, together with legal and financial institutions. It appears that cities, where social institutions are present, produce better economic results, are more attractive to investors, and have a lower unemployment rate. The following text presents the importance of these institutions in Silesia. The analysis indicates that there exist 41 such entities in the region, mostly social cooperatives, mutual insurance companies, enterprise development foundations, social enterprises, nongovernmental organizations and social activity centres. The article is focused on activities of selected institutions, their importance to the region, a specific character of functioning and main achievements. Definitions of basic concepts, connected directly with social economy, serve as a starting point. The article also discusses the importance of this sector, and the significance of organizations and institutions favourable to the proper functioning of the citizens.
\end{abstract}

Słowa kluczowe: instytucje ekonomii społecznej; organizacje pozarządowe; spółdzielnie socjalne; śląskie

Key words: social economy institutions; nongovernmental organizations; social cooperatives; Silesia 


\section{Wprowadzenie}

W społecznościach lokalnych coraz częściej poszukuje się aktywnych i skutecznych sposobów wspierania zatrudniania osób wykluczonych. W tym zakresie kluczowe okazały się instrumenty prawno-organizacyjne i finansowe (Kogut-Jaworska, 2008: 83; Filipiak, Ruszała, 2009: 82-105). W ramach pierwszego aspektu zwraca się uwagę na znaczenie określonych instytucji. Chodzi tu nie tylko o tzw. podmiotowe wspieranie biznesu, lokalnej przedsiębiorczości przez powstające inkubatory, ale też o popieranie funkcjonowania instytucji zaliczanych do ekonomii społecznej. Dostrzeżono, że miasta, które mają tego typu podmioty, osiągają dużo lepsze wyniki gospodarcze, są atrakcyjniejsze dla inwestorów i cechują się mniejszym bezrobociem. Najlepiej może o tym zaświadczyć pozycja Bielska-Białej jako subregionalnego bieguna wzrostu (Sobala-Gwosdz, 2010: 139). Wpływ na to miało również wiele innych czynników demograficznych i gospodarczych.

Niniejszy tekst przedstawia znaczenie zwłaszcza tych podmiotów, które zalicza się do sektora, czy też gałęzi ekonomii, określanej mianem gospodarki społecznej. Analiza wykazała, że w całym województwie śląskim funkcjonuje 41 instytucji, zwłaszcza spółdzielni socjalnych, towarzystw ubezpieczeń wzajemnych, fundacji rozwoju przedsiębiorczości, przedsiębiorstw społecznych, organizacji pozarządowych czy centrów aktywności społecznej. W artykule skupiono się na działalności wybranych instytucji, ukazano ich rolę w regionie, specyfikę funkcjonowania, główne osiągnięcia. Przyjęto następujące kryteria doboru instytucji do analizy: typ instytucji, okres działalności, lokalizacja. Zasadniczym celem jest ukazanie różnorodności tej gałęzi ekonomii oraz znaczenia instytucji ekonomii społecznej nie tylko dla miast, ale również dla społeczności lokalnych i osób wykluczonych.

Punktem wyjścia w artykule jest zdefiniowanie podstawowych pojęć związanych w sposób bezpośredni z ekonomią społeczną, a także odniesienie się do roli tego sektora i znaczenia klimatu organizacyjnego oraz instytucjonalnego, korzystnego dla prawidłowego funkcjonowania tych podmiotów.

\section{Cechy ekonomii spolecznej}

Od stosunkowo niedawna termin ekonomia społeczna jest niezwykle popularny. Złożyło się na to kilka przyczyn. Po pierwsze, nastąpił wzrost badań nad tym zjawiskiem, po drugie, wiele dyscyplin naukowych zaczęło się nim zajmować, a po trzecie, w związku z przeobrażeniami życia społecznego i gospodarczego tego typu podmioty zaczynają odgrywać coraz większą rolę, zwłaszcza w zakresie pomocy osobom niepełnosprawnym i wykluczonym oraz w zakresie rozwoju regionów (Głąbicka, 2011: 341-352). Jest to bowiem ten sektor, który może przyczyniać się do inkluzji społecznej, a przez to mieć wpływ na wzrost gospodarczy (Czemiel-Grzybowska, 2012; Narski, 2012). Poza wymienionymi wyżej czynnikami T. Kaźmierczak przyczyn wzrostu zainteresowania ekonomią społeczną dopatruje się w rozwoju technologicznym (zwłaszcza informatyki, telekomunikacji), prowadzącym do zmniejszania się ilości pracy, zmianie wzorów podziału pracy, zysków i kosztów w przekrojach społecznych, wyczerpaniu się możliwości popytowej polityki społeczno-gospodarczej, konieczności tworzenia nowego, instytucjonalnego ładu, który pozwoliłby zredukować nierozwiązywalne problemy i dał szanse zrównoważonego i trwałego rozwoju, zgodnie z aksjologią równości i sprawiedliwości społecznej (cyt. za: Gagacka, 2009: 458).

W najbardziej uproszczony sposób przez ekonomię społeczna można rozumieć każdą działalność ekonomiczną, w której zakłada się osiąganie zysku w sensie społecznym, a nie czysto ekonomicznym. Działalność gospodarcza służy wypracowywaniu nadrzędnych celów społecznych (Waszkiewicz, Podławiak, 2010: 6). Pomimo to do instytucji ekonomii społecznej zalicza się jedynie instytucje prowadzące działalność o charakterze gospodarczym. Zgodnie z defini- 
cją opracowaną przez europejską sieć badawczą EMES za podmiot ekonomii społecznej uznaje się taką aktywność, która prowadzona jest na podstawie zdefiniowanych celów społecznych, gdzie zyski w założeniu są reinwestowane w te cele lub we wspólnotę, a nie w celu maksymalizacji zysku lub zwiększenia dochodu udziałowców czy też właścicieli (Moroń, 2009: 420). Według EMES podmiot ekonomii społecznej ma spełniać kryteria zarówno ekonomiczne, jak i społeczne. Do pierwszej grupy zalicza się: prowadzenie działalności w sposób względnie ciągły i regularny, stosowanie instrumentów ekonomicznych, niezależność w stosunku do instytucji publicznych, ponoszenie ryzyka ekonomicznego oraz istnienie choćby nielicznego płatnego personelu. Pośród kryteriów społecznych pierwszorzędne znaczenie ma orientacja na społecznie użyteczny cel przedsięwzięcia, poza tym oddolny, obywatelski charakter inicjatywy, specyficzny, demokratyczny system zarządzania, możliwie wspólnotowy charakter aktywności oraz ograniczona repartycja osiąganych zysków (Gagacka, 2009: 461; Waszkiewicz, Podławiak, 2010: 7; Gagacka, Głąbicka, 2011: 16-17).

Biorąc pod uwagę podmioty ekonomii społecznej, najczęściej wskazuje się na przedsiębiorstwa społeczne. Ich zadaniem jest nie tylko wytwarzanie określonych dóbr i usług, ale także mobilizacja kapitału społecznego, generowanie innowacyjności oraz poszerzanie rynku przez włączanie do uczestnictwa w nim osób dotychczas wykluczonych. To specyficzna podgrupa ekonomii społecznej, ukierunkowana na rynek, stanowiąca część wspólną wszystkich sektorów (Frączek, Pokora, 2012: 7).

Przy badaniu i wyjaśnianiu roli podmiotów ekonomii społecznej ważne znaczenie ma autonomia gospodarcza tych instytucji. Są one bowiem praktycznie w całości odrębnymi organizacjami, niezależnymi zwłaszcza od władz publicznych. Jedynym punktem spornym jest działalność centrów integracji społecznej, czyli tzw. CIS-ów, tworzonych i nadzorowanych przez organy samorządu terytorialnego. Niejednokrotnie funkcjonują jako pewnego rodzaju nieformalne „części” składowe danego samorządu i tak też są traktowane. Poza tym należy się odnieść do działalności gospodarczej prowadzonej przez podmioty ekonomii społecznej, które powołane zostały jako wspólne przedsięwzięcia kilku organizacji i instytucji (zwłaszcza pozarządowych) (Waszkiewicz, Podławiak, 2010: 8). Inną kwestią jest właściwe ustalenie i rozumienie kryteriów społecznych. W każdym przypadku powinny być one bezwzględnie i w całości spełniane przez każdą instytucję, którą chcemy nazwać podmiotem ekonomii społecznej (Waszkiewicz, Podławiak, 2010: 9).

\section{Instytucje ekonomii społecznej}

W literaturze przedmiotu najczęściej do podmiotów ekonomii społecznej zalicza się zakłady aktywności zawodowej, spółdzielnie oraz centra integracji społecznej. Poza tym wymienia się prowadzące działalność gospodarczą organizacje pozarządowe - fundacje, stowarzyszenia, spółki z ograniczoną odpowiedzialnością niedziałające dla zysku i wioski tematyczne (Campion, 2012: 24; Moroń, 2012: 111; Gagacka, 2009: 459; Sobolewski i in., 2009). Z kolei K. Kietlińska do grona instytucji ekonomii społecznej zalicza: przedsiębiorstwa społeczne, spółdzielnie, organizacje wzajemnościowe, przedsiębiorstwa tworzące miejsca pracy dla osób niepełnosprawnych, instytucje, których celem jest przeciwdziałanie bezrobociu, instytucje działające na rzecz ograniczania wykluczania społecznego (Kietlińska, 2010: 128). W zdecydowanej większości przypadków podmioty te zatrudniają osoby niepełnosprawne w stopniu znacznym i umiarkowanym, kładąc przy tym nacisk na rehabilitację zawodową oraz bezrobotnych czy uzależnionych od alkoholu i narkotyków, po ukończonych programach terapeutycznych (Czemiel-Grzybowska, 2012: 67).

Z wyróżnionego grona podmiotów szczególną wagę przypisuje się spółdzielniom. Najczęściej wymienia się spółdzielnie inwalidów i niewidomych, spółdzielnie pracy i socjalne. Te ostatnie, 
Ustawą z dnia 27 kwietnia 2006 roku o spółdzielniach socjalnych (Dz.U. nr 94, poz. 651) określono jako przedsiębiorstwa społeczne. Ich celem jest prowadzenie wspólnej działalności, opierając się na osobistej pracy członków. Spółdzielnie socjalne działają na rzecz społecznej i zawodowej reintegracji swoich członków. Mogą je założyć: osoby bezrobotne, bezdomni realizujący indywidualny program wychodzenia z bezdomności, uzależnieni od alkoholu, po zakończeniu programu psychoterapii w zakładzie lecznictwa odwykowego, uzależnieni od narkotyków lub innych środków odurzających, po zakończeniu programu terapeutycznego w zakładzie opieki zdrowotnej, chorzy psychicznie, zwalniani z zakładów karnych, uchodźcy realizujący indywidualny program integracji, osoby niepełnosprawne (Piotrowski, 2009: 476-477; Głąbicka, 2011: 354-355). Spółdzielnię socjalną może założyć co najmniej pięć osób spełniających wymienione wyżej warunki, nie więcej jednak niż pięćdziesiąt (Sobolewski i in., 2009).

Na uwagę zasługują także centra integracji społecznej, które, obok klubów integracji społecznej i zakładów aktywności zawodowej, zaliczane są do tzw. podmiotów „,nowej ekonomii społecznej" (Czemiel-Grzybowska, 2012: 104-114). Ich działalność reguluje Ustawa z dnia 13 czerwca 2003 roku o zatrudnieniu socjalnym (Dz.U. nr 122, poz. 1143 z późn. zm.) Są one jednostkami organizacyjnymi utworzonymi przez organy samorządu terytorialnego (wójtów, burmistrzów, prezydentów miast) lub organizację pozarządową, realizujące reintegrację zawodową i społeczną przez prowadzenie dla osób zagrożonych wykluczeniem społecznym programów edukacyjnych, obejmujących m.in. nabywanie umiejętności zawodowych, przekwalifikowanie lub podwyższanie kwalifikacji zawodowych oraz nabywanie innych umiejętności niezbędnych do codziennego życia. Centra nie stanowią samodzielnych podmiotów prawnych, lecz są formą prawną adresowaną do instytucji oraz organizacji pozarządowych pracujących z osobami zagrożonymi wykluczeniem społecznym. W grupie beneficjentów są te same podmioty, które mogą założyć spółdzielnię socjalną. (Sobolewski i in., 2009).

Stosunkowo nowym rozwiązaniem są tzw. wioski tematyczne, czyli takie miejscowości, w których mieszkańcy decydują się na działalność zarobkową w wybranej dziedzinie gałęzi, czyniąc z niej lokalną specjalizację, np. pieczenie chleba. Ta kluczowa kompetencja zostaje następnie podzielona na nieskończenie wiele wątków i sposobów produkcji, sprzedaży czy usług informacyjnych, edukacyjnych i turystycznych. Specjalizacją wsi może być dosłownie wszystko, obok wypieku chleba może to być uprawa czy hodowla zachowawcza ginących gatunków i odmian, a nawet robienie najsmaczniejszych i najbardziej aromatycznych powideł śliwkowych w kraju i zgłębianie wiedzy na ich temat. W każdym przypadku specjalizacja zależy od samych mieszkańców, od ich decyzji i aktywności. Najlepiej jednak, gdy można opierać się na tym, co w danej miejscowości się znajduje - osobliwościach przyrody, unikatowej architekturze, historii bądź też na umiejętnościach samych mieszkańców. Poza tym wiele zależy od samych władz lokalnych i promocji danej miejscowości. Oferta, jaką wieś wspólnie tworzy, kierowana jest zwykle do mieszkańców miast, a także do określonej grupy docelowej: hobbistów, pasjonatów, turystów. Miejscowość oferuje daną usługę czy produkt, stając się pewnego rodzaju firmą z misją, główną linią produkcji, zaś mieszkańcy są jej pracownikami. W wyniku ich zaangażowania i pracy tworzy się łańcuch powiązań, w którym każdy ma określone zadania. Cały proces nie jest sformalizowany, nie wymaga rejestracji firmy, potrzebna jest jedynie lokalna umowa między mieszkańcami, która najczęściej przybiera prawną postać lokalnego stowarzyszenia (Sobolewski i in., 2009).

\section{Rola podmiotów ekonomii społecznej}

Podmiotom tradycyjnie zaliczanym do ekonomii społecznej, z uwagi na przedsiębiorczy i ekonomiczny wymiar działania, przypisuje się określone funkcje. Obok tradycyjnych zadań, 
zwłaszcza odnoszących się do integracji społecznej, pełnią one funkcje prorozwojowe, mogą przyczyniać się do modyfikacji zachowań rynkowych i politycznych (Surdej, 2008). Podmioty te odgrywają również komplementarną rolę w stosunku do zadań sektora publicznego. Ważne przy tym, aby szukać możliwości pogodzenia wzrostu gospodarczego na rzecz ograniczania nierówności społecznych. W czasie kryzysu na rynku pracy oraz masowego wyludniania się mniejszych miast i wsi jest to szczególnie ważne (Frączek, Pokora, 2012; Sobolewski, 2009).

Dotychczasowa praktyka działania instytucji ekonomii społecznej pokazuje, że w zakresie rozwoju gmin i rozwiązywania lokalnych problemów mogą one szczególnie wspomóc: aktywizację zawodową i społeczną osób niepełnosprawnych i wykluczonych, przedłużenie aktywności zawodowej, tworzenie dodatkowych możliwości zarobkowych, pozyskiwanie środków zewnętrznych, przeciwdziałanie ucieczce młodych, aktywizację (zawodową i społeczną) starszych mieszkańców, przeciwdziałanie alienacji i anonimowości nowych osiedli, oddłużanie mieszkań komunalnych i spółdzielczych, przeciwdziałanie uzależnieniu od pomocy społecznej, niezaradności życiowej, rosnące wydatki z budżetów. Ponadto działalność podmiotów ekonomii społecznej dla jednostki samorządu terytorialnego może przynieść zwiększenie bazy podatkowej, powstanie nowych miejsc pracy, zatrzymanie odpływu młodych ludzi, a także wydłużenie aktywności zawodowej mieszkańców, znalezienie nowych partnerów szczególnie zainteresowanych rozwojem społeczności lokalnej (Sobolewski, 2009).

Funkcjonując w środowiskach lokalnych, podmioty ekonomii społecznej są ważnymi dostarczycielami usług i produktów, którymi nie jest zainteresowany w sposób bezpośredni sektor komercyjny. Ich oferta jest zróżnicowana i obejmuje usługi opiekuńcze, edukacyjne, przemysł czasu wolnego. Poza tym sektor ekonomii społecznej realizuje ważne zadania w zakresie rozwijania i promowania lokalnych produktów, tzn. niszowych, tradycyjnych dóbr lub usług związanych ze specyfiką regionu (np. dobra i usługi związane z lokalnym dziedzictwem kulturowym, lokalne produkty spożywcze, rzemiosło ludowe itp.) oraz tzw. zielonym biznesem, przyczyniając się do wdrażania zasad zrównoważonego rozwoju. Niewątpliwie rola instytucji zaliczanych do ekonomii społecznej jest znacząca i uzupełniająca w stosunku do tradycyjnych podmiotów gospodarczych (Frączek, Pokora, 2012).

\section{Tworzenie korzystnego otoczenia dla sektora ekonomii społecznej}

Aby instytucje ekonomii społecznej w należyty sposób odgrywały swoją rolę, konieczne jest tworzenie dobrego klimatu organizacyjnego i instytucjonalnego. Po pierwsze, należy zwrócić uwagę na kompetencje pracowników samorządu, po drugie, niezbędne jest partnerskie traktowanie podmiotów ekonomii społecznej podobnie jak przedsiębiorców. Po trzecie, konieczne jest kreowanie zachęt infrastrukturalnych do uruchamiania i prowadzenia takich podmiotów, m.in. przez tworzenie lokalnych inkubatorów ekonomii społecznej, udostępnianie lokali podmiotom społecznym itd. Przykładowo podnoszenie kompetencji pracowników samorządu terytorialnego powinno odbywać się przez wspólne szkolenia z zakresu ogólnej wiedzy dotyczącej teoretycznego i praktycznego funkcjonowania instytucji ekonomii społecznej. Ważnym aspektem funkcjonowania tego typu podmiotów jest budowanie dialogu i zaufania, korzystając z narzędzi partnerstwa zawieranego zarówno w formie powoływanych paktów, jak i grup nieformalnych. Podstawą dla dialogu będzie zwłaszcza wymiana informacji, wspólne omawianie problemów i propozycji rozwiązań oraz otwartość na nowych członków. Niezmiernie ważne jest zaufanie społeczne do urzędu, wiedza, że wesprze on rozpoczętą działalność (kupi usługi, udostępni preferencyjnie lokal, będzie wspierał przez działania urzędu pracy), zaufanie do przedsiębiorców, że potraktują powstający podmiot ekonomii społecznej jako partnera 
do współpracy oraz pomoc ze strony innych podmiotów trzeciego sektora, aby chciały one zarówno wykorzystać potencjał tej instytucji, jak i traktować ją jako partnera (Sobolewski, 2009).

W obszarze wsparcia powstawania i działania podmiotów ekonomii społecznej należy podjąć następujące działania:

- tworzyć inkubatory ekonomii społecznej,

- kreować świadomą politykę wsparcia dla podmiotów ekonomii społecznej,

- kierować usługi i zakupy w stronę podmiotów ekonomii społecznej,

- tworzyć partnerstwa z podmiotami ekonomii, zarówno publiczno-prywatne do realizacji określonych zamierzeń lub inwestycji (np. prowadzenia przedszkoli, opieki nad osobami zależnymi, porządkowania terenów zielonych, promocji, prowadzenia informacji turystycznej), jak również dotyczące dostarczania określonych usług,

- prowadzić politykę promocyjną i informacyjną z zakresu ekonomii społecznej,

- wprowadzić aktywne formy reintegracji społecznej i zawodowej ośrodków pomocy społecznej i powiatowego urzędu pracy, ukierunkowane na powstawanie i wsparcie podmiotów ekonomii społecznej przez pracę socjalną ukierunkowaną na zakładanie podmiotów, włączanie się w ich działanie oraz kierowanie beneficjentów ośrodków pomocy społecznej i powiatowego urzędu pracy na odbycie praktyk w podmiotach ekonomii społecznej.

W obszarze wsparcia wykorzystania potencjału podmiotów w lokalnym rozwoju społecznym i gospodarczym należy uwzględnić:

- aktywizację osób do tej pory wykluczonych z rynku pracy lub mających trudności w dostępie do niego,

- wykorzystanie innowacyjności w działaniu i umiejętności łączenia potencjału osób i instytucji, a także pozyskiwania środków zewnętrznych,

- wytypowanie obszarów współpracy w ramach partnerstwa publiczno-prywatnego (Sobolewski, 2009).

\section{Ekonomia społeczna a kryzys gospodarczy}

W aktywnie rozwijającym się sektorze ekonomii społecznej upatruje się szans uelastycznienia rynku pracy zwłaszcza w odniesieniu do osób wykluczonych, którym znacznie trudniej jest się na nim utrzymać. Jest to tym istotniejsze, że kryzys gospodarczy panujący w Europie spowodował dramatyczne w skutkach konsekwencje na rynku pracy, wymagające coraz większej interwencji ze strony władz lokalnych i regionalnych (Zioło, 2011; Dorocki, 2011).

Również ze strony Unii Europejskiej podjęto przedsięwzięcia służące wsparciu tego sektora. Mają one przede wszystkim charakter instytucjonalny i finansowy. W ramach pierwszego aspektu Komisja Europejska zaleca państwom członkowskim wspieranie zwłaszcza przedsiębiorstw społecznych, które w czasie kryzysu mogą być ratunkiem dla wielu „oburzonych”. Działania te powinny obejmować zwłaszcza ułatwienia w zakresie dostępu do finansowania prywatnego, wprowadzenie mechanizmu pożyczkowego, tworzenie narzędzi pozwalających na dokładniejsze poznanie sektora i uwarunkowań jego działalności, wzmocnienie potencjału w sferze zarządzania oraz profesjonalizację i sieciowanie przedsiębiorstw społecznych (http:// www.ekonomiaspoleczna.pl/wiadomosc/760006.html).

\section{Charakterystyka wybranych instytucji ekonomii społecznej w województwie śląskim}

Rozwój sektora ekonomii społecznej w województwie śląskim jest w ścisły sposób powiązany z kilkoma tendencjami. Pierwszą z nich jest możliwość uzyskania określonych korzyści finansowych w związku z udziałem tego sektora w tworzeniu PKB oraz korzyści społecznych w postaci rozwoju formy integracji społeczno-zawodowej. Druga tendencja dotyczy inicjowa- 
nia różnych form aktywności w obszarze społecznym, co wpisuje się w cele strategiczne Unii Europejskiej, takie jak: spójność społeczna, pełne zatrudnienie, walka z ubóstwem i wykluczeniem społecznym, partycypacja obywateli, stały rozwój (Czemiel-Grzybowska, 2012). Trzecią kwestią jest możliwość finansowania różnych projektów środkami z Unii Europejskiej. Ważnym aspektem jest także wizerunek społeczny regionu, którego władze pomagają wykluczonym.

Na podstawie zebranych raportów można przyjąć, że liczba podmiotów ekonomii stopniowo ewoluowała. Przykładowo, według danych Ministerstwa Pracy i Polityki Społecznej, w 2009 r. funkcjonowało 9 zakładów aktywności zawodowej, z czego 2 zakłady o charakterze usługowym oraz 7 o charakterze wytwórczym i usługowym. Na terenie województwa funkcjonowały również 53 warsztaty terapii zajęciowej (Miżejewski, 2010: 11-12).

Według Bazy KLON/JAWOR oraz portalu www.ekonomiaspoleczna.pl, zajmujących się monitoringiem tych instytucji, w 2012 r. funkcjonowało ich 41. Zaliczono tutaj wszystkie typy podmiotów, czyli centra integracji społecznej, spółdzielnie socjalne, przedsiębiorstwa społeczne, zakłady aktywności zawodowej i towarzystwa ubezpieczeń wzajemnych. Wiele zmieniło się w zakresie liczby spółdzielni socjalnych. Przykładowo, według danych Ogólnopolskiego Związku Rewizyjnego Spółdzielni Socjalnych, w roku 2010 funkcjonowało 37 spółdzielni socjalnych, z kolei Baza KLON/JAWOR ich liczbę szacuje na 39, z czego 5 jest w stanie likwidacji. Najwięcej podmiotów tego typu zlokalizowanych jest w Bytomiu, Gliwicach, Chorzowie oraz Cieszynie. Dużą popularnością cieszą się także centra integracji społecznej, usytuowane w Jaworznie, Łazach, Mikołowie, Tychach i Zawierciu. W profilu działalności dominują usługi porządkowe, recykling oraz roboty budowlane i remonty.

Ponadto, jak podaje portal www.ekonomiaspoleczna.pl, występuje znaczące zróżnicowane przestrzenne koncentracji podmiotów ekonomii społecznej. Najwięcej z nich zlokalizowanych jest w miastach GOP-u, Gliwicach, a także w Częstochowie, Bielsku-Białej i Cieszynie (www.ekonomiaspoleczna.pl/mapstest?data=\&state_province[]=1311).

Do modelowych przykładów ekonomii społecznej można zaliczyć:

- Chrześcijańskie Stowarzyszenie Dobroczynne w Łazach,

- Stowarzyszenie Pomocy Wzajemnej „Być razem” w Cieszynie,

- Bielskie Stowarzyszenie Artystyczne „Teatr Grodzki”,

- Centrum Rozwoju Inicjatyw Społecznych „Cris” w Rybniku,

- Stowarzyszenie Współpracy Regionalnej w Chorzowie,

- Spółdzielnię Socjalną „Szansa i Wsparcie” w Chorzowie,

- Spółdzielnię Socjalną „Nowy Horyzont” w Cieszynie (Miżejewski, 2010).

Spośród wymienionych powyżej instytucji w sposób szerszy odniesiono się do wybranych, określonych na podstawie następujących kryteriów: typ podmiotu (pierwszy ma charakter warsztatu terapii zajęciowej, kolejne dwie są ważnymi dla miasta i regionu stowarzyszeniami, zaś ostatni jest spółdzielnią socjalną), okres działalności i lokalizacja. Wybór tych podmiotów podyktowany był ukazaniem kilku tendencji w zakresie rozwoju sektora ekonomii społecznej. Po pierwsze, różnorodnością podmiotów, po drugie, okazało się, że wiele instytucji może pochwalić się wieloma interesującymi inicjatywami, mającymi również cykliczny charakter. Po trzecie zaś, ich usytuowanie zwłaszcza w Bielsku-Białej i Cieszynie doborze wpisuje się w kreowanie polityki społecznej, a zwłaszcza przezwyciężanie problemu bezrobocia wśród osób wykluczonych.

Pierwsza z wybranych instytucji - Chrześcijańskie Stowarzyszenie Dobroczynne w Łazach - ma charakter warsztatów terapii zajęciowej i powstała w grudniu 2004 r. dzięki ścisłej współpracy lokalnych stowarzyszeń i samorządowi w Łazach. Warsztaty stały się dopełnieniem działań na rzecz osób niepełnosprawnych, bowiem tego typu placówka przeznaczona dla dorosłych była 
brakującym ogniwem działalności na rzecz integracji społecznej niepełnosprawnych z terenu gminy. Dzięki podejmowanym wysiłkom prowadzone są wszechstronne działania zmierzające do pomocy i edukacji osób niepełnosprawnych (http://www.chsd.pl/).

Stowarzyszenie Pomocy Wzajemnej „Być razem” zostało założone w 1996 r. przez ludzi młodych, pedagogów, psychologów, terapeutów, pracowników socjalnych, prawników, studentów, powodowanych przeświadczeniem o niewystarczającej skuteczności zinstytucjonalizowanego systemu pomocy społecznej. Od początku istnienia Stowarzyszenie stało się ważnym lokalnym partnerem kreującym politykę społeczną na terenie miasta i wpisało się w system pomocy jako jego integralny i wartościowy element. Przy współpracy z Gminą Cieszyn i holenderskimi fundacjami Stowarzyszenie „Być Razem” w 1997 r. uruchomiło swój pierwszy całodobowy ośrodek, działający z dużym powodzeniem do dzisiaj pod nazwą Centrum Profilaktyki Edukacji i Terapii „KONTAKT”. Stowarzyszenie oferuje wszechstronną pomoc psychologiczną i prawną, a także możliwość uczestniczenia w grupach terapii zajęciowej i grupach wsparcia. W 1999 r. w ramach rządowego programu Stowarzyszenie uruchomiło hostel dla kobiet i dzieci, ofiar przemocy i innych przestępstw, następnie młodzieżowy klub „Graciarnia” i Centrum Wolontariatu (http://bycrazem.com/).

Na Podbeskidziu zlokalizowane jest Bielskie Stowarzyszenie „Teatr Grodzki”, istniejące od 1999 r. Jego utworzenie było uwieńczeniem wysiłków artystów, pedagogów i animatorów kultury. Instytucja prowadzi działalność na rzecz grup zagrożonych wykluczeniem społecznym, ograniczonych w dostępie do świata kultury i sztuki. Adresatami inicjatyw Stowarzyszenia są zarówno dzieci i młodzież, jak i osoby w podeszłym wieku. Wśród nich znajdują się niepełnosprawni fizycznie i umysłowo, młodzież sprawiająca kłopoty wychowawcze i ze środowisk dysfunkcyjnych, osoby uzależnione, wychowankowie domów dziecka oraz placówek resocjalizacyjnych i opiekuńczych. Pośród głównych obszarów działania Stowarzyszenia znajdują się: warsztaty artystyczne, warsztaty terapii zajęciowej, zakład aktywności zawodowej, poradnictwo zawodowe oraz działalność wydawnicza. Jedną z inicjatyw Stowarzyszenia, wpisującą się w szeroko postrzegany nurt ekonomii społecznej, było utworzenie w 2004 r. Zakładu Aktywności Zawodowej „Zakład Introligatorsko-Drukarski. Teatr Grodzki”. Podmiot ten zatrudnia kilkadziesiąt osób niepełnosprawnych oraz kilkunastu pracowników kadry obsługowo-rehabilitacyjnej. Zakład jest przedsiębiorstwem całkowicie podporządkowanym potrzebom pracujących w nim niepełnosprawnych, a jednocześnie nastawionym na aktywizację i społeczną rehabilitację pracowników. Jego celem, tak jak każdego przedsiębiorstwa, jest przychód i zysk, który zależy od wydajności pracy, a więc również od procesu rehabilitacji społecznej pracowników (http://www.teatrgrodzki.pl/).

Kolejnymi podmiotami branymi pod uwagę w niniejszym artykule są spółdzielnie socjalne. Pierwsza z nich powstała w 2007 r. w wyniku współpracy kilku organizacji pozarządowych Spółdzielnia Socjalna „Szansa i Wsparcie”. Oferuje ona usługi opiekuńcze placówkom służby zdrowia (usługi pomocniczego personelu medycznego - sanitariuszek szpitalnych) oraz osobom starszym i niepełnosprawnym (usługi opiekuńcze). Nowatorskie działania podmiotu przejawiają się w organizacji marszów nordic walking. Inna spółdzielnia socjalna - „Nowy Horyzont” - została założona w 2008 r. w Cieszynie. Świadczy ona usługi zwłaszcza w zakresie: specjalistycznego i niespecjalistycznego sprzątania, zagospodarowania terenów zielonych, drobnych remontów i zimowego utrzymania chodników. W kompleksowy sposób współpracuje z podmiotami publicznymi i samorządowymi (Spółdzielnia Socjalna „Szansa i Wsparcie” (http://www.ekonomiaspoleczna.pl/files/ekonomiaspoleczna.pl/public/Atlas_dobrych_praktyk/ atlas_dobrych_praktyk_nowe/23atlas_Dobrych_Praktyk_Chorzow_ver052009.pdf:, http://www. fundacjabycrazem.pl/spoldzielnia-socjalna-nowy-horyzont-2.). 


\section{Wsparcie podmiotów ekonomii społecznej w województwie śląskim}

Podmioty ekonomii społecznej w województwie śląskim mogą liczyć na wsparcie instytucjonalne i finansowe. Świadczą o tym chociażby rozwinięte narzędzia promocyjne, np. opracowanie broszur i ulotek informacyjnych, zrealizowane projekty i zorganizowane konferencje. Celem tych przedsięwzięć jest propagowanie „dobrych praktyk” w zakresie ekonomii społecznej, zwiększanie wiedzy na ten temat wśród instytucji rynku pracy oraz ośrodków pomocy i integracji społecznej, ukazanie podmiotów ekonomii społecznej jako użytecznych sposobów aktywizacji zawodowej oraz zatrudniania osób wykluczonych. Poza tym zwraca się uwagę na popularyzowanie usług świadczonych przez te instytucje w województwie śląskim.

Egzemplifikacją wskazanych przedsięwzięć może być profesjonalne opracowanie strony internetowej poświęconej możliwościom dofinansowania środkami Unii Europejskiej wybranych projektów wspierających działalność podmiotów ekonomii społecznej. Poprzez stronę internetową udzielane jest poradnictwo na temat aspektów prawnych, księgowych i merytorycznych związanych z ich funkcjonowaniem. Działa również forum dyskusyjne służące wymianie informacji i doświadczeń z zakresu ekonomii społecznej. Innym przykładem może być broszura informacyjna Wizytówki śląskich podmiotów ekonomii społecznej, prezentująca rozwój omawianych instytucji w regionie, ze szczególnym uwzględnieniem danych teleadresowych, profilu działalności i opisu świadczonych usług. Podobną funkcję pełni także publikacja pt. Przewodnik po ekonomii społecznej, stanowiąca kompendium wiedzy na ten temat (czym jest ów sektor, jakie formy może przyjmować, skąd można pozyskać środki na działalność, zagadnienia prawne, biznesowe, przykłady dobrych praktyk). W zakresie seminariów i konferencji dobrym przykładem może być spotkanie pt. „Perspektywy rozwoju sektora ekonomii społecznej w województwie śląskim”, zorganizowane w ramach projektu systemowego Regionalnego Ośrodka Polityki Społecznej Województwa Śląskiego - „Kształcenie i doradztwo dla kadr pomocy i integracji społecznej województwa śląskiego", realizowanego w ramach Priorytetu VII „Promocja integracji społecznej” Programu Operacyjnego Kapitał Ludzki 2007-2013, współfinansowanego ze środków Europejskiego Funduszu Społecznego. Wzięli w niej udział członkowie zespołów zadaniowych przygotowujący wieloletni regionalny plan działań na rzecz promocji i upowszechnienia ekonomii społecznej oraz rozwoju instytucji sektora ekonomii społecznej i jej otoczenia w regionie, a także kadra zarządzająca instytucji pomocy i integracji społecznej województwa śląskiego, zainteresowana problematyką ekonomii społecznej (http://www.ekonomiaspoleczna.pl/x/485971, http://ropskatowice.pl/content/konferencja-ptperspektywy-rozwoju-sektora-ekonomii-spolecznej-w-wojewodztwie-slaskim, http://pl.scribd. com/doc/27832423/2010-02-Przewodnik-po-ekonomii-spo\%C5\%82ecznej).

Podmioty ekonomii społecznej mogą liczyć również na pomoc finansową. Od 2008 r. w ramach Programu Operacyjnego Kapitał Ludzki wdrażane jest poddziałanie 7.2.2. „Wsparcie ekonomii społecznej”. Efektem jest finansowanie projektów, których celem jest pomoc w utworzeniu i funkcjonowaniu (w tym wzmożenia potencjału) instytucji sektora ekonomii społecznej. Chodzi tu zwłaszcza o zapewnienie dostępu do usług prawnych, księgowych, marketingowych, doradztwo (indywidualne i grupowe), system szkoleń, ułatwienia w tworzeniu inkubatorów społecznych oraz wspieranie rozwoju partnerstw lokalnych na rzecz ekonomii społecznej. Projekty realizowane w ramach tego poddziałania powinny przyczyniać się do zapewnienia instytucjonalnego wsparcia ekonomii społecznej. Dla województwa śląskiego jako wskaźniki określono: co najmniej trzy instytucje wspierające ekonomię społeczną, które otrzymały wsparcie, 26 inicjatyw ekonomii społecznej wspartych z Europejskiego Funduszu Społecznego oraz 2191 osób, które otrzymają wsparcie w ramach podmiotów ekonomii społecznej. Efektem było zawarcie łącznie 31 umów z projektodawcami na realizację wsparcia ekonomii społecznej na łączną kwotę 15,7 mln zł. 
Poza działaniami czysto projektowymi lub wspieranymi ze źródeł budżetowych zaczęła funkcjonować infrastruktura wsparcia, czyli konkretne ośrodki, które wspierają w wymiarze doradczo-szkoleniowym podmioty ekonomii społecznej. Czasem oczywiście organizacje te są również beneficjentem projektowym. Do najważniejszych można zaliczyć m.in. Stowarzyszenie Wspierania Organizacji Pozarządowych Most z Katowic, Katowickie Forum Organizacji Socjalnych, Stowarzyszenie Współpracy Regionalnej z Chorzowa oraz Stowarzyszenie Centrum Rozwoju Inicjatyw Społecznych z Rybnika (http://www.funduszeeuropejskie.gov.pl/poradnikbeneficjenta/pokl/strony/7.2.2-wsparcie-ekonomii-spolecznej.aspx).

W zakresie organizacyjnym i szkoleniowym ważną rolę odgrywają tzw. inkubatory, często określane mianem inkubatorów społecznej przedsiębiorczości. Zwykle ich zadania sprowadzają się do organizowania doradztwa indywidualnego, szkoleń z zakresu podstaw ekonomii, elementów prawa pracy, prawa spółdzielczego, funkcjonowania firmy, coachingu indywidualnego i działań promocyjnych. Jako grupy docelowe tych usług najczęściej wskazuje się bezrobotnych, zarejestrowane na terenie regionu - podmioty ekonomii społecznej oraz instytucje rynku pracy i integracji społecznej (tab. 1).

Okazuje się zatem, że wsparcie podmiotów ekonomii społecznej w województwie śląskim przybiera kompleksową, złożoną postać i wymaga wielowymiarowego podejścia.

Tab. 1. Ośrodki wspierania ekonomii społecznej w województwie śląskim

\begin{tabular}{|c|c|c|c|c|}
\hline Lp. & Instytucja & Grupa docelowa & Oferta & $\begin{array}{c}\text { Podmiot } \\
\text { realizujący } \\
\text { projekt }\end{array}$ \\
\hline 1. & $\begin{array}{l}\text { Katowickie } \\
\text { Centrum Ekonomii } \\
\text { Społecznej } \\
\text { - wsparcie dla } \\
\text { sektora ekonomii } \\
\text { społecznej }\end{array}$ & $\begin{array}{l}\text { - osoby fizyczne w zakresie } \\
\text { doradztwa indywidual- } \\
\text { nego i szkoleń } \\
\text { • podmioty ekonomii } \\
\text { społecznej zarejestrowa- } \\
\text { ne na terenie woj. - } \\
\text { w zakresie doradztwa } \\
\text { i promocji } \\
\text { - instytucje rynku pracy } \\
\text { i integracji społecznej - } \\
\text { w zakresie promocji } \\
\text { i budowy lokalnego } \\
\text { partnerstwa na rzecz } \\
\text { rozwoju ekonomii } \\
\text { społecznej }\end{array}$ & $\begin{array}{l}\text { • doradztwo indywidualne } \\
\text { • szkolenia dla osób mających zamiar } \\
\text { utworzyć spółdzielnię socjalną } \\
\text { • coaching indywidualny inkubowanych } \\
\text { spółdzielni } \\
\text { • doradztwo dla działających podmiotów } \\
\text { ekonomii społecznej } \\
\text { • działania mające na celu powołanie } \\
\text { partnerstwa lokalnego na rzecz } \\
\text { rozwoju ekonomii społecznej - konfe- } \\
\text { rencje, artykuły, spotkania robocze } \\
\text { - promocję ekonomii społecznej } \\
\text { i zatrudnienia w sektorze ekonomii } \\
\text { społecznej }\end{array}$ & $\begin{array}{l}\text { Fundacja } \\
\text { Gaudete }\end{array}$ \\
\hline 2. & $\begin{array}{l}\text { Spółdzielnie } \\
\text { socjalne drugiej } \\
\text { generacji }\end{array}$ & $\begin{array}{l}\text { - osoby bezrobotne } \\
\text { (w tym długotrwale } \\
\text { bezrobotne) } \\
\text { - organizacje pozarządo- } \\
\text { we zainteresowane } \\
\text { zakładaniem spółdzielni } \\
\text { socjalnych }\end{array}$ & $\begin{array}{l}\text { • opracowywanie, wraz z zainteresowa- } \\
\text { nymi osobami, koncepcji działania } \\
\text { spółdzielni socjalnych, w tym pomoc } \\
\text { w przygotowaniu biznesplanu } \\
\text { • szkolenia w zakresie spółdzielczości } \\
\text { socjalnej } \\
\text { • szkolenie zawodowe przygotowane } \\
\text { pod kątem profilu działalności } \\
\text { konkretnej spółdzielni socjalnej } \\
\text { • wsparcie w pozyskaniu zleceń dla } \\
\text { spółdzielni socjalnych } \\
\text { • pomoc w montażu finansowym } \\
\text { przedsięwzięć } \\
\text { - doradztwo dla powstających } \\
\text { spółdzielni socjalnych i monitoring ich } \\
\text { działania po założeniu }\end{array}$ & $\begin{array}{l}\text { Stowarzy- } \\
\text { szenie } \\
\text { Współpracy } \\
\text { Regionalnej }\end{array}$ \\
\hline
\end{tabular}




\begin{tabular}{|c|c|c|c|c|}
\hline Lp. & Instytucja & Grupa docelowa & Oferta & $\begin{array}{c}\text { Podmiot } \\
\text { realizujący } \\
\text { projekt }\end{array}$ \\
\hline 3. & $\begin{array}{l}\text { Sieć inkubatorów } \\
\text { społecznej } \\
\text { przedsiębiorczości }\end{array}$ & $\begin{array}{l}\text { - osoby fizyczne } \\
\text { - funkcjonujące już } \\
\text { podmioty ekonomii } \\
\text { społecznej na terenie } \\
\text { województwa śląskiego }\end{array}$ & $\begin{array}{l}\text { - doradztwo ekspertów ds. księgowości, } \\
\text { prawnych i marketingu prowadzone } \\
\text { w ramach dyżurów, zarówno } \\
\text { stacjonarnie w poszczególnych } \\
\text { inkubatorach, jak również mobilne } \\
\text { (z dojazdem do beneficjenta ostatecz- } \\
\text { nego) } \\
\text { • szkolenia w ramach usług szkolenio- } \\
\text { wych w każdym podmiocie } \\
\text { - pomoc przy tworzeniu i wsparcie } \\
\text { działania stron WWW podmiotów } \\
\text { ekonomii społecznej } \\
\text { - promocja ekonomii społecznej }\end{array}$ & $\begin{array}{l}\text { Gliwickie } \\
\text { Centrum } \\
\text { Organizacji } \\
\text { Pozarządo- } \\
\text { wych, } \\
\text { z ramienia } \\
\text { Miasta } \\
\text { Gliwice }\end{array}$ \\
\hline 4. & $\begin{array}{l}\text { Inkubator } \\
\text { - Ośrodek } \\
\text { Wspierania } \\
\text { Instytucji Ekonomii } \\
\text { Społecznej }\end{array}$ & $\begin{array}{l}\text { - spółdzielnie socjalne; } \\
\text { - spółdzielnie pracy } \\
\text { - spółdzielnie inwalidów } \\
\text { i niewidomych } \\
\text { - organizacje pozarządo- } \\
\text { we zlokalizowane na } \\
\text { terenie województwa } \\
\text { śląskiego }\end{array}$ & $\begin{array}{l}\text { - inkubowanie podmiotów ekonomii } \\
\text { społecznej przez zapewnienie } \\
\text { infrastruktury technicznej } \\
\text { • Punkt Informacyjny - w nim można } \\
\text { uzyskać różne informacje dotyczące } \\
\text { zasad zakładania stowarzyszenia lub } \\
\text { fundacji, prawnych aspektów funkcjono- } \\
\text { wania organizacji pozarządowych } \\
\text { • szkolenia - zapewnienie kompleksowej } \\
\text { ścieżki wsparcia obejmującego tematy: } \\
\text { co to jest ekonomia społeczna, } \\
\text { podstawy prawne i finansowe } \\
\text { ekonomii społecznej, lobbing, } \\
\text { partnerstwo } \\
\text { - doradztwo i coaching z zakresu prawa, } \\
\text { księgowości, marketingu oraz } \\
\text { doradztwa finansowego }\end{array}$ & $\begin{array}{l}\text { Rudzka } \\
\text { Agencja } \\
\text { Rozwoju } \\
\text { INWESTOR } \\
\text { Sp. z o.o. }\end{array}$ \\
\hline
\end{tabular}

Źródło: opracowanie własne na podstawie: www.gaudete.katowice.opoka.org.pl, www.kces.pl, www.swr.pl, www.gcop.gliwice.pl; inkubatory.slask.pl, www.rarinwestor.pl, http://www.ekonomiaspoleczna.pl/x/485971.

\section{Zakończenie}

Niewątpliwie rozwój ekonomii społecznej w regionie śląskim przynosi zróżnicowane efekty. W każdym jednak przypadku jest dużym wyzwaniem i szansą. Jako zjawisko stosunkowo nowe w polskiej rzeczywistości rodzi wątpliwości, niejasności, wymaga udoskonaleń. Konieczne jest podjęcie szeroko zakrojonych działań promocyjnych przybliżających ideę ekonomii społecznej i związanych z nią korzyści.

Ekonomia społeczna, jak to wykazano w odniesieniu do praktyki funkcjonowania niektórych podmiotów, jest zwłaszcza szansą dla osób zagrożonych wykluczeniem społecznym. Tradycyjne instrumenty aktywizacji zawodowej i społecznej osób bezrobotnych, niepełnosprawnych, osób wykluczonych czy zagrożonych wykluczeniem społecznym często okazują się nieskuteczne. Ponadto system pomocy społecznej powoduje raczej uzależnienie podopiecznych od instytucji pomocowych i ugruntowanie pasywnych postaw na rynku pracy. Ekonomia społeczna przyczynia się do rozwoju samodzielności, przedsiębiorczości wśród grup defaworyzowanych, odwołując się do idei solidarności i pomocy wzajemnej. Podmioty ekonomii społecznej dają swym członkom nie tylko szansę (często jedyną) na uzyskanie zatrudnienia, ale też stanowią efektywną metodę integracji społecznej - realizacja misji społecznej i działalność na rzecz ludzi, nie zaś maksymalizacja zysków. 
W artykule odniesiono się także do kreowania lokalnego rynku pracy i szeroko pojętego rozwoju. W wielu przypadkach sektor ten aktywizuje całą społeczność, stając się przy tym dostarczycielem usług i produktów deficytowych lub nieopłacalnych z punktu widzenia prywatnego przedsiębiorcy, nastawionego wyłącznie na wysokie zyski finansowe.

Pomimo wielu zalet podmiotom ekonomii społecznej niezwykle trudno jest przetrwać zwłaszcza w warunkach kryzysu gospodarczego. Stąd niezwykle ważne jest tworzenie sprzyjającego otoczenia, klimatu, zarówno ze strony innych instytucji, jak i jednostek, władz lokalnych. Konieczna jest też partnerska współpraca, polegająca m.in. na zlecaniu usług podmiotom ekonomii społecznej przez instytucje i organizacje z sektora administracji i biznesu.

\section{Literatura}

Campion, M. (2012). Rola samorządu we wspieraniu lokalnej i regionalnej przedsiębiorczości. Kraków: Wydawnictwo Naukowe UP.

Czemiel-Grzybowska, W. (2012). Zarzadzanie przedsiębiorstwem społecznym w procesie konwergencji. Warszawa.

Dorocki, S. (2011). Wpływ kryzysu gospodarczego na przemiany struktur regionalnych Francji, Prace Komisji Geografii Przemystu Polskiego Towarzystwa Geograficznego, 17, 67-86.

Filipiak, B., Ruszała, J. (2009). Instytucje otoczenia biznesu. Rozwój, wsparcie, instrumenty. Warszawa: Centrum Doradztwa i Informacji Difin.

Frączek, M., Pokora, M. (red.), Ekonomia społeczna w Małopolsce - w stronę przedsiębiorczości społecznej. Kraków, 13-29.

Gagacka, M. (2009). Nierówności społeczne jako wyzwanie dla ekonomii społecznej. W: K. Głąbicka, M. Gagacka (red.), Wspótczesne wyzwania dla lokalnej polityki społecznej. Radom: PTPS i Politechnika Radomska, 458-467.

Gagacka, M., Głąbicka, K. (2011). Zarządzanie przedsiębiorstwem społecznym, Radom: Wydawnictwo Politechniki Radomskiej.

Głąbicka, K. (2011). Rola ekonomii społecznej integracji i aktywizacji zawodowej grup defaworyzowanych na rynku pracy. W: R.C. Horodeński, C. Sadowska-Snarska (red.), Integracja społeczna przez pracę. Aspekty makroekonomiczne. Białystok: Wyższa Szkoła Ekonomiczna; Warszawa: Instytut Pracy i Spraw Socjalnych, 338-264.

Guz, H., Handzlik, A. (2012). Działania Urzędu Marszałkowskiego Województwa Małopolskiego na rzecz rozwoju ekonomii społecznej w Małopolsce. W: M. Frączek, M. Pokora (red.), Ekonomia społeczna w Małopolsce - w stronę przedsiębiorczości społecznej. Kraków: Fundacja Gospodarki i Administracji Publicznej, 13-29.

Gwosdz, K., Sobala-Gwosdz, A. (2010). Ośrodki wzrostu i obszary stagnacji w województwie śląskim oraz sposoby pobudzenia ich rozwoju. W: A. Sobala-Gwosdz (red.), Badanie trendów rozwojowych $w$ województwie ślaskim poprzez wyznaczenie ośrodków wzrostu i obszarów stagnacji. Bielsko-Biała: Strada Consultung Piotr Kurowski, 137-158.

Kietlińska, K. (2010). Rola trzeciego sektora w społeczeństwie obywatelskim, Warszawa: Difin.

Kogut-Jaworska, M. (2008). Instrumenty interwencjonizmu lokalnego w stymulowaniu rozwoju gospodarczego, Warszawa, CeDeWu.pl.

Miżejewski, C. (2010). Polityka rozwoju ekonomii społecznej w województwie ślaskim, Poznań: Stowarzyszenie na rzecz Spółdzielni Socjalnych.

Moroń, D. (2009). Współpraca samorządu terytorialnego i organizacji pozarządowych jako sposób realizacji zadań lokalnej polityki społecznej. W: K. Głąbicka, M. Gagacka (red.), Współczesne wyzwania dla lokalnej polityki społecznej. Radom: PTPS i Politechnika Radomska, 418-421. 
Moroń, D. (2012). Organizacje pozarządowe - fundament społeczeństwa obywatelskiego, Wrocław: Wydawnictwo Uniwersytetu Wrocławskiego.

Narski, Z. (2012). Ekonomia społeczna, Toruń: Wydawnictwo Adam Marszałek .

Piotrowski, M. (2009). Spółdzielnia socjalna jako instrument lokalnej strategii rozwiązywania problemów społecznych. W: K. Głąbicka, M. Gagacka (red.), Współczesne wyzwania dla lokalnej polityki spotecznej. Radom: PTPS i Politechnika Radomska, 469-480.

Sobolewski, A. i inni. (2009). Ekonomia społeczna w kreowaniu polityki lokalnej gmin i powiatów, Szczecin: Stowarzyszenie Czas Przestrzeń Tożsamość.

Surdej, A. (2008). Gospodarka - wspólnota - solidarność, Przedsiębiorczość - Edukacja, 4, 204-213.

Waszkiewicz, M., Podławiak, G. (2010). Ekonomia społeczna - popularne pojęcie. W: A. Waszkiewicz i inni (red.), Ekonomia społeczna kluczem do rozwoju regionu. Koszalin: Wojewódzki Urząd Pracy, 6-11.

Zioło, Z. (2011). Wpływ światowego kryzysu na tempo wzrostu gospodarki i światowych korporacji, Prace Komisji Geografii Przemystu Polskiego Towarzystwa Geograficznego, 17, 9-32.

\section{Źródla internetowe}

http://bycrazem.com/

www.chsd.pl/

www.ekonomiaspoleczna.pl

www.funduszeeuropejskie.gov.pl/poradnikbeneficjenta/pokl/strony/7.2.2-wsparcie-ekonomii-spolecznej.aspx www.gaudete.katowice.opoka.org.pl

www.gcop.gliwice.pl

www.inkubatory.slask.pl

www.kces.pl

www.ropskatowice.pl/content/konferencja-pt-perspektywy-rozwoju-sektora-ekonomii-spolecznej-wwojewodztwie-slaskim

www.swr.pl

www.teatrgrodzki.pl/

Sabina Sanetra-Pólgrabi, dr, Uniwersytet Pedagogiczny im. Komisji Edukacji Narodowej w Krakowie. Absolwentka politologii na Uniwersytecie Pedagogicznym im. KEN w Krakowie. Zajmuje się problematyką współpracy transgranicznej i zagadnieniem rozwoju regionalnego i lokalnego. Przygotowuje swoją pierwszą publikację książkową pt. Funkcjonowanie euroregionów na pograniczu poludniowym Polski po 1993 roku (analiza porównawcza trzech euroregionów: Śląsk Cieszyński, Beskidy i Tatry).

Sabina Sanetra-Pólgrabi, PhD, Pedagogical University of Cracow.

Sabina Sanetra-Półgrabi, a graduate of Political Science at the Pedagogical University of Cracow. Research interests include: cross-border cooperation, as well as issues related to regional and local governments. The author is in the course of preparing her first book, entitled Functioning of Euroregions in the southern Polish borderland after 1993 (a comparative analysis of three euroregions: Ślask Cieszyński (Cieszyn Silesia), Beskidy (the Beskid Mountains), Tatry (the Tatra Mountains).

Adres/Address: $\quad$ Uniwersytet Pedagogiczny im. Komisji Edukacji Narodowej w Krakowie Instytut Politologii ul. Podchorążych 2, 30-638 Kraków, Polska e-mail: sab_san@poczta.onet.pl 